\title{
TABAKALI CAM ELYAF/EPOKSİ KOMPOZİTLERİN DARBE DAVRANIŞININ DENEYSEL OLARAK İNCELENMESİ
}

\author{
Ayșe ÖNDÜRÜCÜ1*, Ali KARACAN²
}

${ }^{1}$ Süleyman Demirel Üniversitesi, Mühendislik Fakültesi, Makina Mühendisliği Bölümü, Isparta, Türkiye

${ }^{2}$ Süleyman Demirel Üniversitesi, Fen Bilimleri Enstitüsü, Makina Mühendisliği A.B.D., Isparta, Türkiye

\begin{tabular}{|c|c|}
\hline Anahtar Kelimeler & Öz \\
\hline $\begin{array}{l}\text { Cam elyaf/epoksi } \\
\text { Tabakalı kompozitler } \\
\text { Düsük hızlı darbe } \\
\text { Darbe enerjisi } \\
\text { Hasar }\end{array}$ & 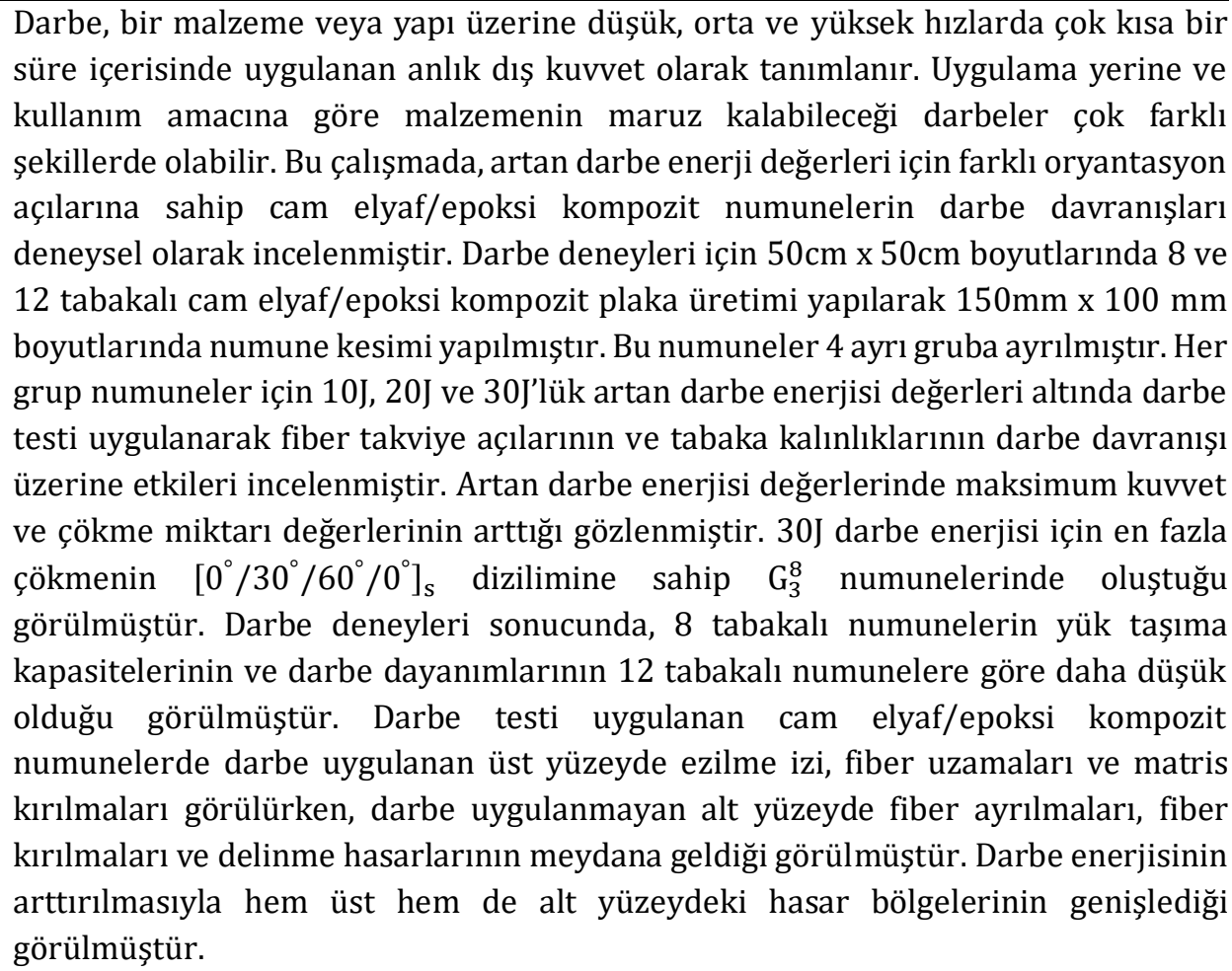 \\
\hline
\end{tabular}

\section{EXPERIMENTAL INVESTIGATION ON THE IMPACT BEHAVIOR OF LAMINATED GLASS FIBER/EPOXY COMPOSITES}

\begin{tabular}{l} 
Keywords \\
\hline Glass fiber/epoxy \\
Laminated composites \\
Low velocity impact \\
Impact energy \\
Damage
\end{tabular}

\section{Keywords}

Laminated composites

Low velocity impact

Damage

\begin{abstract}
Impact can be defined as the momentary external force applied to a material or structure at a low, medium, or high speed within a very short period of time. Depending on the application and the purpose of use, the impact that the material may be subjected to can be very different. In this study, the impact behaviors of glass fiber / epoxy laminated composite specimens with different orientation angles for increasing impact energy values were experimentally investigated. For impact tests, 8 and 12 layered glass fiber/epoxy composite materials were manufactured in dimensions of $50 \mathrm{~cm} \times 50 \mathrm{~cm}$, and specimens were cut in dimensions of $150 \mathrm{~mm} \times 100 \mathrm{~mm}$. These samples are divided into 4 separate groups. For each group of samples, impact tests were performed under increasing impact energy values of 10J, 20J and 30J to investigate the effects of fiber reinforcement angles and layer thickness on impact behavior. As a result of the impact tests, It was also observed that the maximum force and the displacement
\end{abstract}

\footnotetext{
* ilgili yazar / Corresponding author: ayseondurucu@sdu.edu.tr
} 
increased with increasing impact energy values. it was seen that the load carrying capacities of the 8 layered samples and the impact strengths were lower than those of the 12 layered samples. It has been observed that the maximum collapse for 30J impact energy is in the specimens with $\left[0^{\circ} / 30^{\circ} / 60^{\circ} / 0^{\circ}\right]_{\mathrm{s}}$ array. It was observed that small fiber segregations and matrix fractures were observed on impacted top face of glass fiber/epoxy composite samples for low impact energies. In addition, it was seen that fiber breakage and perforation damage occurred by increasing the impact energy. Fiber segregations, fiber breakages and perforation damage were observed on the bottom faces of the composite specimens where no impact was applied. It is also observed that the areas of the damage have grown with increasing impact energy values.

\section{Alıntı / Cite}

Öndürücü, A., Karacan, A., (2018). Tabakalı Cam Elyaf / Epoksi Kompozitlerin Darbe Davranışının Deneysel Olarak İncelenmesi, Journal of Engineering Sciences and Design, 6(3), 435-447.

\section{Yazar Kimliği / Author ID (ORCID Number) $\quad$ Makale Süreci / Article Process}

A. ÖNDÜRÜCÜ, 0000-0002-0319-4256 $\quad$ Başvuru Tarihi /Submission Date

A.KARACAN, 0000-0001-9225-4830 $\quad$ Revizyon Tarihi / Revision Date

Kabul Tarihi / Accepted Date
Yayım Tarihi / Published Date

06.12 .2017

18.07.2018

26.07.2018

21.09.2018

\section{Giriş}

Havacılık, denizcilik ve otomotiv sanayi, yapı sektörü, spor araçları, sağlık ve ulaşım gibi birçok alanda kullanılan kompozit malzemelerin düşük hız altında aldıkları darbeler büyük önem arz etmektedir. Darbelerin kompozit yapıların performansına etkileri kompozit malzemelerin kullanımında kısıtlayıcı bir etkendir. Bu nedenle kompozit malzemelerin düşük hızlardaki darbe problemi önemli pratik ve teorik uygulamaları temsil eder (Uyaner vd., 2007). Darbe, bir malzeme veya yapı üzerine düşük, orta ve yüksek hızlarda çok kısa bir süre içerisinde uygulanan anlık dış kuvvet olarak tanımlanır. Uygulama yerine ve kullanım amacına göre malzemenin maruz kalabileceği darbeler çok farklı şekillerde olabilir (Kara, 2012). Genel olarak, darbeler düşük hızlı veya yüksek hızlı olarak sinıflandırılırlar fakat bu kategoriler arasında açık bir geçiş yoktur. Yapılan araştırmalar bu geçişin belirlenmesinde henüz net bir sonucun elde edilemediğini göstermektedir. $\mathrm{Bu}$ konuda yapılmış çalışmalardan bir kısmı düşük hızlı darbeyi ki bunlar statikmiş gibi düşünülebilir; hedefin rijitliğine, malzeme özelliklerine ve çarpan cismin kütle ve rijitliğine bağlı olarak 1 ile $10 \mathrm{~m} / \mathrm{s}$ arasında değişen hızlar olarak değerlendirilmesi gerektiğini savunmaktadırlar (Ceyhun ve Turan, 2003).

Kompozit malzemelerin en hassas oldukları yükleme durumu tabaka veya fibere dik yükleme halidir. Malzeme kalınlık doğrultusunda tabaka düzlemine nazaran daha zayıf olduğundan, enine darbeye maruz

kaldığında toplam yük taşıma kapasiteleri düşer ve hasara uğrar (Ceyhun ve Turan, 2003). Tabakalı kompozitler birçok mühendislik alanında kullanılır ve yabancl cisimler tarafindan darbeye maruz kalabilirler. Kompozit yapının üretim, bakım ve servis işlemleri sırasında darbeden kaynaklanan hasarlar ortaya çıkabilir. Kullanım sırasındaki darbeye örnek olarak, uçağın kalkış ve iniş sırasında lastiklerin yüksek hız kazanmasından sonra pistten firlayan taş ve küçük parçacıkların sebep olduğu darbe verilebilir. Üretim ve bakım sırasında kullanılan takımlar yapı üzerine düşürülebilir. $\mathrm{Bu}$ durumda darbe hızları küçük fakat etkisi büyüktür. Tabakalı kompozit yapılar benzer metalik yapılara nazaran darbe hasarına daha duyarlıdır. Kompozit malzemelerde ortaya çıkan hasarlar kimi zaman gözle görülebilir. Bazı durumlarda ise düșük hızlı darbeler tabakalar üzerinde gözle görülen hasarlar oluşturmamasına rağmen kompozitin iç yapısında matris çatlağı, matris kırılması, fiber-matris arayüzey hasarı, delaminasyon ve/veya fiber kırılması şeklinde hasarlara sebep olabilirler. Bu hasarlar, mukavemette önemli derecede bir düşüşe sebep olur (Ceyhun ve Turan, 2003). Bu nedenle kompozit yapılar üzerine yabancı cisim darbelerinin etkileri anlaşılmalıdır ve tasarım aşamasında uygun önlemler dikkate alınmalıdır. Bundan dolayı bu çalışmada, cam elyaf/epoksi kompozit malzemelerin düşük hızlı darbe davranışları deneysel olarak incelenerek tabaka kalınlığının ve oryantasyon açılarının cam elyaf/epoksi kompozitlerin darbe davranışına etkileri araştırılmıştır.

Çalışmanın bilimsel yazın taraması bölümünde tabakalı malzemelerin düşük hızda darbe davranışı ile ilgili çalışmalara, materyal yöntem kısmında numune üretimi ve darbe test cihazı hakkında bilgilere yer verilmiştir. Araştırma bulguları kısmında numunelerin darbe davranışlarını gözlemlemek için darbe enerjisi-maksimum kuvvet grafiği, darbe enerjisi-maksimum çökme grafiği, kuvvet-çökme eğrileri, absorbe edilen enerji-zaman eğrileri, kuvvetzaman eğrileri, çökme-zaman eğrileri ve hız - zaman eğrileri oluşturulmuştur. Sonuç ve tartışma kısmında ise çalışma kısaca özetlenmiş ve elde edilen deneysel sonuçlar değerlendirilerek yorumlanmıştır. 


\section{Bilimsel Yazın Taraması}

Tabakalı kompozit malzemelerin düşük hızlı darbe davranışları üzerine deneysel çalışmalar yapılmış ve analitik yöntemler geliştirilmiștir: Kompozit malzemelerin dinamik yükleme altındaki davranışı üzerine ilk çalışmalar 1970'lerin başında yapılmıștır (Sierakowski vd., 1971). Bu alandaki ilerlemeler darbe modelleri ve muayene yöntemleri geliștirilerek devam etmiştir (Sierakowski ve Chaturvedi, 1997; Abrate, 1998). Tabakalı kompozit malzemelerin farklı oryantasyon açllarında dizilimlerinin belirlenmesi, farklı tabaka kalınlıklarında darbeye maruz bırakılması ve uygulanan darbe enerji değerlerinin değiştirilmesinin darbe davranışları üzerine etkileri ile ilgili araștırmalar yapılmıştır (Kessler ve Bledzki, 1999; Datta vd., 2004; Caprino vd., 2004; Hosur vd., 2005).

Tabakalı kompozit numunelerin düşük hızlı darbe yükü altındaki davranışları, vurucu hızlarının ve tabaka dizilimlerinin, kompozit levhanın darbe davranışına etkileri, farklı vurucu ağırlığına göre numunelerin darbe davranışları üzerine çalışmalar yapılmıştır. Ayrıca farklı çarpışma hızlarında yapılan testlerde kuvvet-yer değiştirme grafikleri yardımıyla malzemenin enerji absorbsiyon yeteneği de araștırılmıştır (Mili ve Necib, 2001; Naik vd., 2002; Belingardi ve Vadori, 2003). Önceki çalışmaların ışığında E-camı/epoksi tabakalı kompozitler üzerine düşük hızlı darbenin düzlem boyuttaki etkileri ve plaka boyutlarının malzemede oluşan hasara etkileri araştırılmıştır (Aslan vd., 2003; Uyaner vd., 2007). Düşük hızlı darbeye maruz E-camı/epoksi kompozit yapılardaki hasar ilerlemeleri, farklı darbe enerjilerindeki hasar modları, darbe hasarının neden olduğu hasarlar ve kritik burkulma yüklerinin darbe davranışına etkilerinin belirlenmesi üzerine çalışmalar yapılmıștır (Baucom ve Zikry, 2005; Aktaş vd., 2009; Kıratll, 2012). Başka bir çalışmada, S2 cam/epoksi ve aramid/epoksi kompozit plakların iki farklı enerji seviyesindeki (20J ve 30J) darbe davranışları deneysel ve nümerik olarak incelenmiștir (Berk vd., 2016).

Bu çalışmada, farklı oryantasyon açısına sahip cam elyaf/epoksi kompozit numunelerin artan darbe enerji değerlerindeki darbe davranışları deneysel olarak incelenmiştir. Düşük hızlı darbe deneyleri için 8 ve 12 tabakalı farklı kalınlıkta cam elyaf/epoksi kompozit numuneler kullanılmıştır. Bu kompozitlerin fiber takviye açılarının ve tabaka kalınlıklarının darbe davranışı üzerine etkileri incelenmiştir.

\section{Materyal ve Yöntem}

Deneysel çalışmada kullanılan 8 ve 12 tabakalı $50 \mathrm{~cm}$ x $50 \mathrm{~cm}$ boyutlarında cam elyaf / epoksi kompozit plakalar Fibermak Mühendislik firması tarafından imal edilmiştir. Kompozitin üretiminde fiber malzeme olarak $300 \mathrm{gr} / \mathrm{m}^{2}$ yoğunluğa sahip tek yönlü cam fiber kumaş kullanılmıştır. Reçine malzemesi olarak da F21P epoksi ve F-22P sertleștirici kullanılmıștır. 100 gr epoksiye 21 gr sertleştirici karıştırılarak reçine sistemi oluşturulmuştur. Daha sonra el yatırma yöntemi ile üzerlerine epoksi-sertleștirici karışımından oluşan reçine sistemi sürülen prepregler bir gün boyunca bekletilmiştir. Reçine jelleştikten sonra sıcak pres yöntemi ile kompozit malzeme imalatı gerçekleștirilmiştir. $120^{\circ} \mathrm{C}$ 'de $8-10$ bar basınç altında 1 saat boyunca kürleme işlemi uygulanmıştır. Şekil 1'de kompozit plakaların üretimi ile ilgili bir fotoğraf verilmiştir.

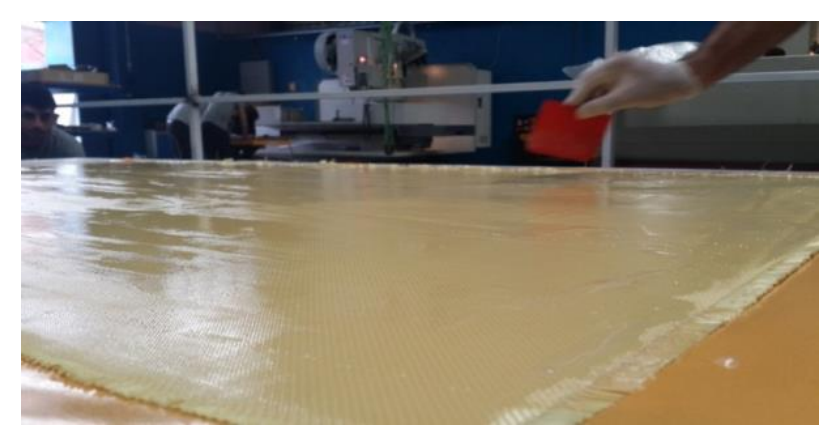

Şekil 1. Kompozit plakaların üretimi

Üretimi yapılan kompozit malzemeler 4 ayrı gruba ayrılmıştır. 3 grup 8 tabakalı, 1 grup da 12 tabakalı olarak tasarlanan kompozit numunelerin tabaka dizilim açıları ve ortalama tabaka kalınlıkları Tablo 1'de verilmiștir. Tabaka kalınlığını karşılaştırabilmek için $G_{1}^{8}$ ve $G_{1}^{12}$ grupları aynı dizilimde seçilmiştir.

Tablo 1. Kompozit plakaların gruplandırılması

\begin{tabular}{|c|c|c|}
\hline Adlandırma & Tabaka Dizilim Açıları & $\begin{array}{c}\text { Ortalama } \\
\text { Kalınlığı }(\mathrm{mm})\end{array}$ \\
\hline $\mathrm{G}_{1}^{8}$ & {$\left[0^{\circ} / 90^{\circ} / 0^{\circ} / 90^{\circ}\right]_{s}$} & 2 \\
\hline $\mathrm{G}_{2}^{8}$ & {$\left[0^{\circ} / 90^{\circ} / 90^{\circ} / 0^{\circ}\right]_{s}$} & 2 \\
\hline $\mathrm{G}_{3}^{8}$ & {$\left[0^{\circ} / 30^{\circ} / 60^{\circ} / 0^{\circ}\right]_{s}$} & 2 \\
\hline $\mathrm{G}_{1}^{12}$ & {$\left[0^{\circ} / 90^{\circ} / 0^{\circ} / 90^{\circ} / 0^{\circ} / 90^{\circ}\right]_{s}$} & 2.8 \\
\hline
\end{tabular}

$\mathrm{G}_{\mathrm{x}}^{\mathrm{y}}$ : $\mathrm{x}$ grup numarasını, $\mathrm{y}$ : tabaka sayısını gösterir.

Üretimi yapılan plakaların kesimleri ve darbe testleri Dokuz Eylül Üniversitesi Makine Mühendisliği Bölümü Kompozit Araştırma Laboratuvarında yapılmıştır. Darbe testi için kompozit plakalar Rubi Diamant DS300-1500 profesyonel kesme makinesi (sulu kesim) yardımıyla $150 \mathrm{~mm}$ x $100 \mathrm{~mm}$ ebatlarında kesilmiștir. Düşük hızlı darbe testleri oda sıcaklığında Fractovis Plus ağırlık düşürme test cihazında yapılmıștır (Şekil 2). Test cihazında bulunan ucu yarım küre şekline sahip olan vurucu $12.7 \mathrm{~mm}$ çapa sahiptir. Testler sırasında kullanılan vurucu kütlesi 4.926 kilogramdır. 


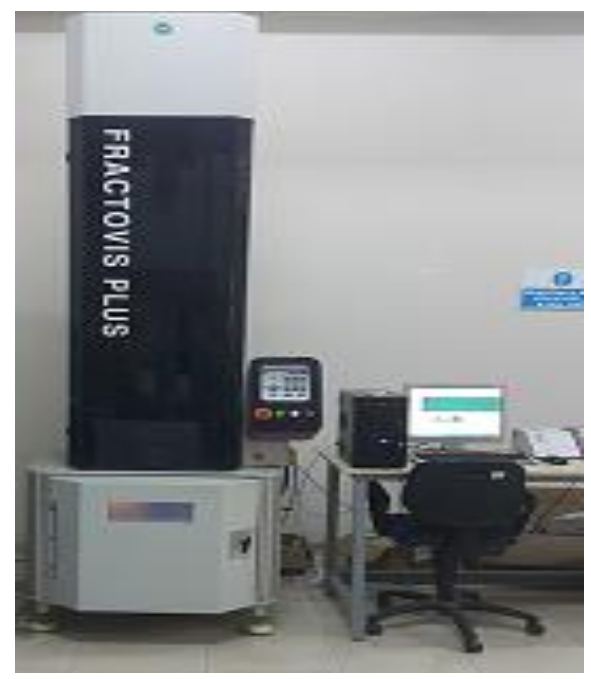

Şekil 2. Fractovis Plus darbe test cihazı

Cihaz içerisindeki pnömatik bir düzenek yardımıyla numunelerin ankastre sınır şartlarında darbe deneylerinin yapılması sağlanmıștır. Numuneler 10J, 20J ve 30J'lük üç farklı enerji seviyesinde darbe yüküne maruz bırakılmıștır. Visual Impact adlı bir yazılımla donatılan cihaz, zamana bağlı olarak vurucu ile numune arasında meydana gelen temas kuvvetini, vurucunun hızını ve numunenin çökme miktarlarını vermektedir. Darbe enerjilerine göre vurucunun numunelere ilk çarpma hızları 10J, 20J ve $30 \mathrm{~J}$ için sirasiyla $2.02 \mathrm{~m} / \mathrm{s}, 2.85 \mathrm{~m} / \mathrm{s}$ ve $3.49 \mathrm{~m} / \mathrm{s}^{\prime}$ dir.

Darbe testlerinde genellikle geri sekme, nüfuziyet ve delinme olmak üzere üç hasar modu oluşur (Şekil 3).

Şekil 3'ten görüldügü üzere, düşük enerjili darbelerde (örneğin geri sekme eğrisi gibi), eğri parabolik bir eğridir ve dağa benzeyen bir șekle sahiptir. Uygulanan darbe enerjisinin artmasiyla meydana gelen kuvvet de artmakta, saplanma ve delinme eğrilerinde de görüldüğü üzere maksimum kuvvet değeri de hemen hemen sabit bir değer olmaktadır. Numunede delinme meydana geldiğinde kuvvetin sıfır olması gerekir fakat vurucu ve numune arasındaki sürtünme nedeniyle eğrinin uç kısmı yatay eksene paralel şekilde ilerler.

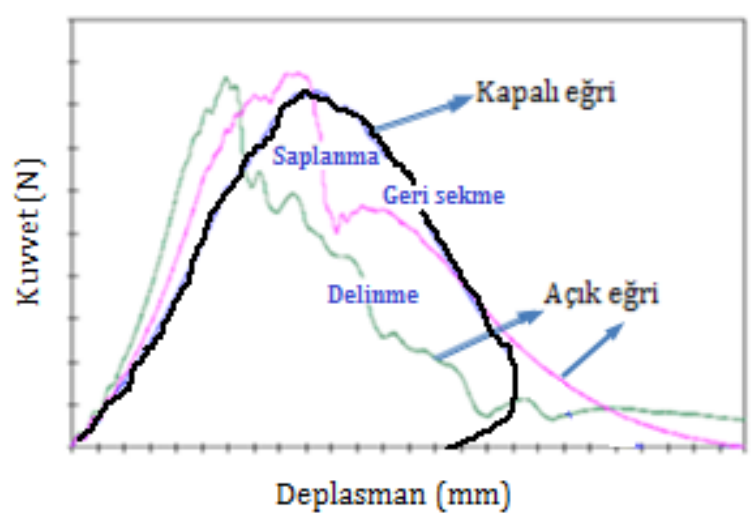

Şekil 3. Kuvvet - yer değiştirme eğrileri

Artan darbe enerjisi altında olușan eğriler kapalı tip ve açık tip eğri olmak üzere iki kısma ayrılır. Kapalı tip eğri vurucunun numuneye temas etmesinden sonra vurucunun numune yüzeyinden geri sekmesiyle oluşan eğrilerdir. Yani uygulanan darbe enerjisinin büyük bir kısmı numune tarafından absorbe edilmiș, absorbe edilmeyen enerji de vurucunun geri sekmesi için kullanılmıştır (Şekil 3). Darbe enerjisi arttırıldığında, geri sekme kısmı azalırken kapalı tip eğri genișler ve çökme de artar. Eğer bir eğri açık tip ise vurucu numuneye ya saplanmıștır ya da numune delinmiştir. Buna göre numuneye saplanan vurucu numune kalınlığı boyunca aşağı doğru hareket eder ve artık numune yüzeyinden geri sekme meydana gelmez. Darbe enerjisi daha da arttırıldığında vurucu numuneye saplanır (penetration), numune kalınlığı boyunca hareket eder ve sonunda da numuneyi delerek alt yüzeyden çıkar yani delinme (perforation) olayı gerçekleşmiș olur. Eğrilerin uç kısımlarına bakılacak olursa, yatay eksenin sonuna doğru kapanan bu kısım numune ve vurucu arasında oluşan sürtünme kısmını ifade etmektedir. Dolayısıyla ulaşılan darbe enerjisi değeri ne kadar arttırılırsa arttırılsın kompozitin daha fazla darbe enerjisini absorbe edemeyeceği anlașılmaktadır (Sayer, 2009; Yıldızhan, 2013).

\section{Araştırma Bulguları}

\subsection{Deneysel Sonuçlar}

Üç farklı tabaka dizilimine sahip 8 tabakalı kompozit numuneler için $10 \mathrm{j}, 20 \mathrm{~J}$ ve $30 \mathrm{~J}$ enerji değerlerinde darbe deneyleri yapılmıștır. Deneyler sonucu elde edilen veriler doğrultusunda $G_{1}^{8}, G_{2}^{8}$ ve $G_{3}^{8}$ gruplarına ait kuvvet -çökme eğrileri çizilmiştir (Şekil 4). 


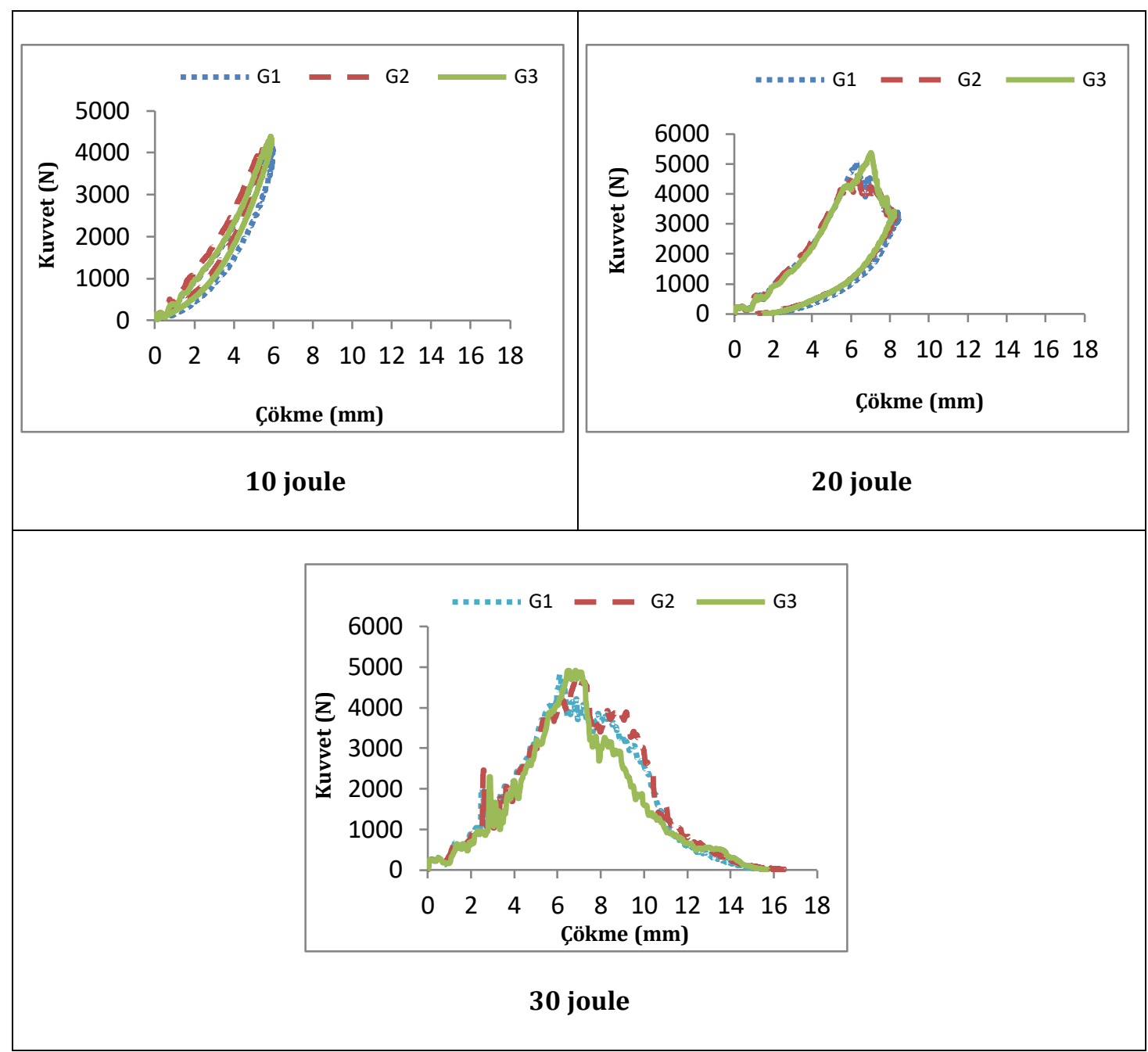

Şekil 4. Farklı tabaka dizilimine sahip 8 tabakalı kompozit numunelerinin kuvvet - çökme eğrileri

Şekil 4'te verilen kuvvet-çökme eğrileri incelendiğinde, her üç joule darbe enerji değeri için de $\mathrm{G}_{1}^{8}, \mathrm{G}_{2}^{8}$ ve $\mathrm{G}_{3}^{8}$ numunelerinin benzer darbe davranışı gösterdikleri görülmektedir. Her üç grup için de $10 \mathrm{~J}$ ve 20J darbe enerji değerlerinde kapalı eğri oluşurken, 30J darbe enerji değerinde ise açlk eğri oluşmuştur. Kapalı eğri görülen numunelerde geri sekme meydana gelirken, açı eğri görülen numunelerde delinme meydana gelmiştir. Tüm darbe enerji değerleri için de $\left[0^{\circ} / 30^{\circ} / 60^{\circ} / 0^{\circ}\right]_{s}$ tabaka dizilimine sahip $\mathrm{G}_{3}^{8}$ grubu numunelerinin diğer gruplara nazaran daha fazla maksimum kuvvet taşıdığı görülmektedir.

Tabaka kalınlıklarının darbe davranışı üzerine etkisini araștırmak amacıyla Șekil 5'te 8 tabakalı $G_{1}^{8}$ ve 12 tabakalı $\mathrm{G}_{1}^{12}$ numuneleri için maksimum kuvvet-darbe enerjisi grafiği çizilmiştir. Şekilden darbe enerji değerlerinin artışı ile maksimum kuvvet değerlerinin de arttığı görülmektedir. Ayrıca 12 tabakalı numunelerin 8 tabakalı numunelere göre maksimum kuvvet değerlerinin daha fazla olduğu görülmektedir. 12 tabakalı numunelerin 8 tabakalı numunelere göre maksimum kuvvet değerlerindeki artış; 10J darbe enerjisi için \%18.77 iken, 30J darbe enerjisi için \%51,36'dır. Buradan hareketle 12 tabakalı numunelerin 8 tabakalı numunelere göre yük taşıma kapasitelerinin daha yüksek olduğu sonucuna varılabilir. Elde edilen bu sonuç literatür ile uyum içindedir. Morais ve arkadaşları da, kompozit tabaka kalınlığının artmasıyla darbe direncinin arttığını belirtmişlerdir (Morais vd., 2005).

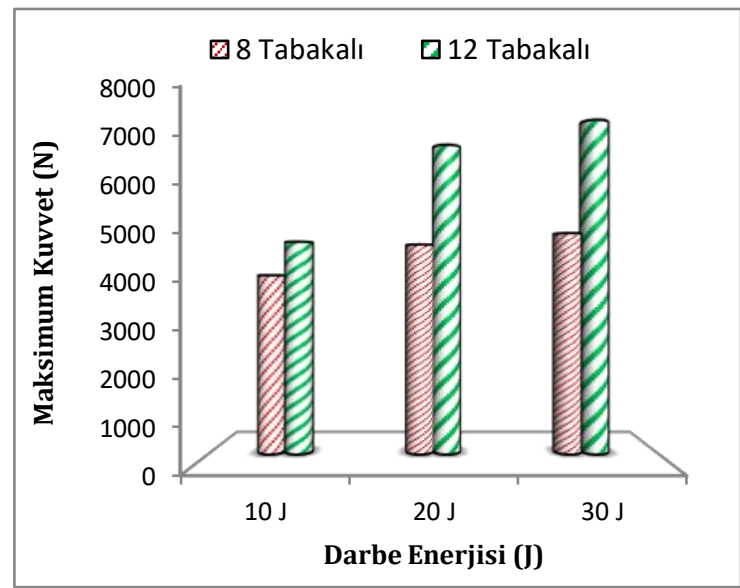

Şekil 5. 8 ve 12 tabakalı numuneler için maksimum kuvvet-darbe enerjisi grafiği

Şekil 6'da 8 tabakalı $G_{1}^{8}$ ve 12 tabakalı $G_{1}^{12}$ konfigürasyonlarına ait kompozit numuneler için 
maksimum çökme-darbe enerjisi grafiği verilmiştir.

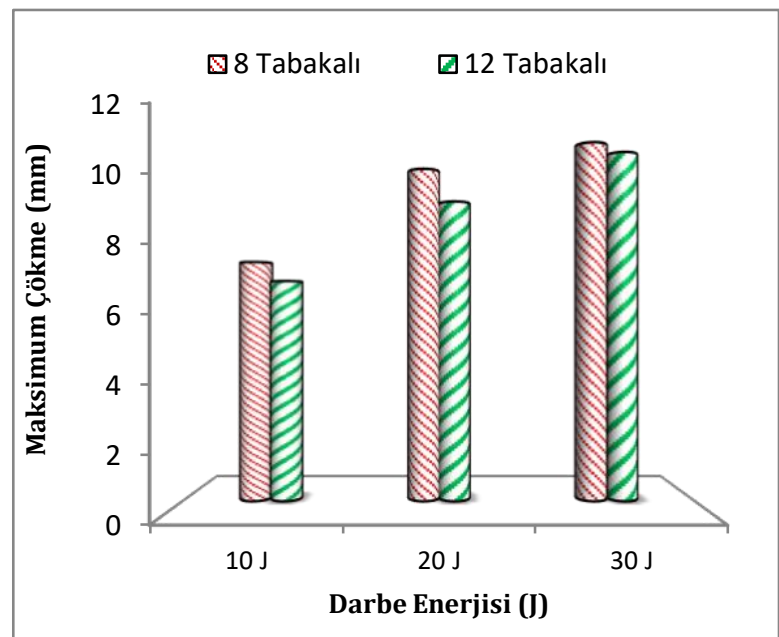

Şekil 6. 8 ve 12 tabakalı numuneler için maksimum çökme-darbe enerjisi grafiği

Şekil 6'dan, darbe enerjisinin artmasıyla çökme değerlerinin arttığı görülmektedir. Ayrıca üç joule enerji değeri için de $2 \mathrm{~mm}$ kalınlığa sahip 8 tabakalı numunelerin çökme değerlerinin, $2.8 \mathrm{~mm}$ kalınlığa sahip 12 tabakalı numunelerin çökme değerlerine nazaran daha fazla olduğu görülmektedir. Buradan hareketle plaka kalınlığı arttıkça çökmelerin azaldığı dolayısıyla darbe dayanımının arttığ sonucuna ulaşılmıştır. Bu sonuç literatür ile de örtüşmektedir. Naik ve arkadașları tarafından kompozitlerin darbe davranışı üzerine yapılan çalışmada da, plaka kalınlığı arttıkça çökmelerin azaldığı ve numunelerin maksimum kuvvet değerlerinin (yük taşıma kapasitelerinin) arttığı rapor edilmiştir (Naik vd., 2000).

Şekil 7'de artan darbe enerjisine maruz $G_{1}^{8}$ ve $G_{1}^{12}$ numunelerinin kuvvet-çökme eğrileri verilmiştir. $\mathrm{Bu}$ şekilden 8 tabakalı $\mathrm{G}_{1}^{8}$ numunelerinde 10J ve 20J için kapalı eğri görülürken, 30J değerinde açık eğri meydana geldiği görülmektedir. Dolayısıyla $\mathrm{G}_{1}^{8}$ numunelerinde $10 \mathrm{~J}$ ve $20 \mathrm{~J}$ enerji değerleri için geri sekme davranışı, 30J enerji değerinde ise delinme meydana gelmiştir. 12 tabakalı $\mathrm{G}_{1}^{12}$ numuneleri için ise her üç joule (10J, 20J ve 30J) darbe enerji değeri için de kapalı eğri oluştuğu görülmektedir. Kapalı eğri vurucunun kompozit numune yüzeyinden geri sekme yaptığının ve numunenin daha az hasara uğradığının göstergesidir. Dolayısıyla 12 tabakalı numunelerde bütün joule değerleri için kapalı eğri oluștuğundan geri sekme davranışı meydana gelmiştir. Bunun yanısıra eğrilerden 12 tabakalı numunelerin 8 tabakalı numunelere nazaran daha fazla kuvvet tașıdığı, çökme değerlerinin de 8 tabakalı numunelere göre daha düşük olduğu görülmektedir. Dolayısıyla aynı joule değerleri için 12 tabakalı numuneler 8 tabakalı numunelere nazaran daha az hasara uğrarlar.

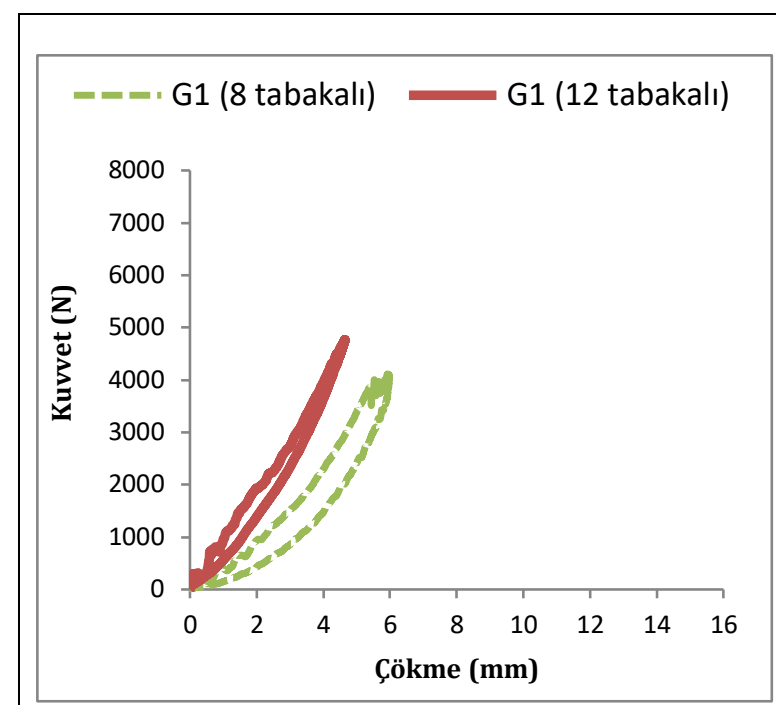

(a) 10 joule

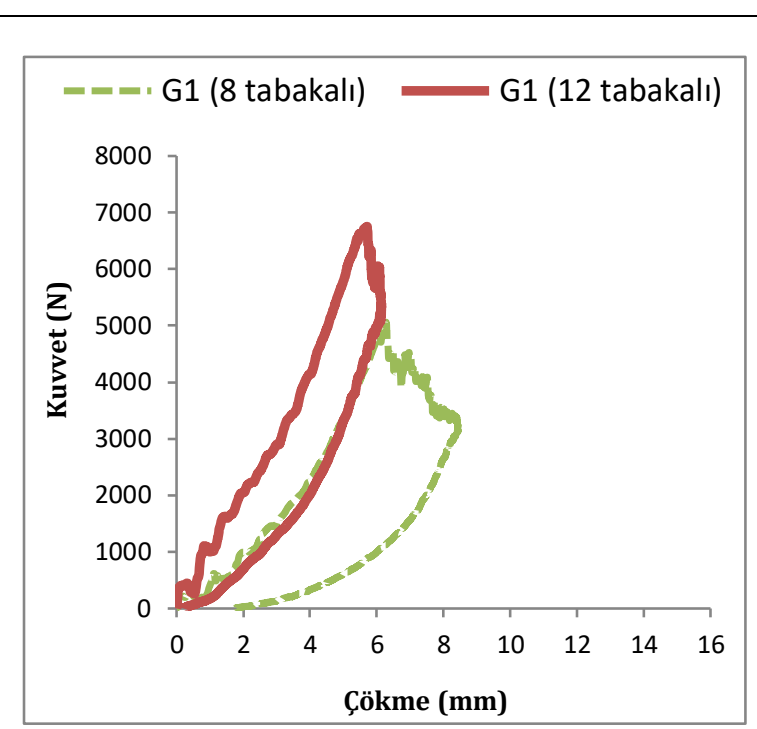

(b) 20 joule

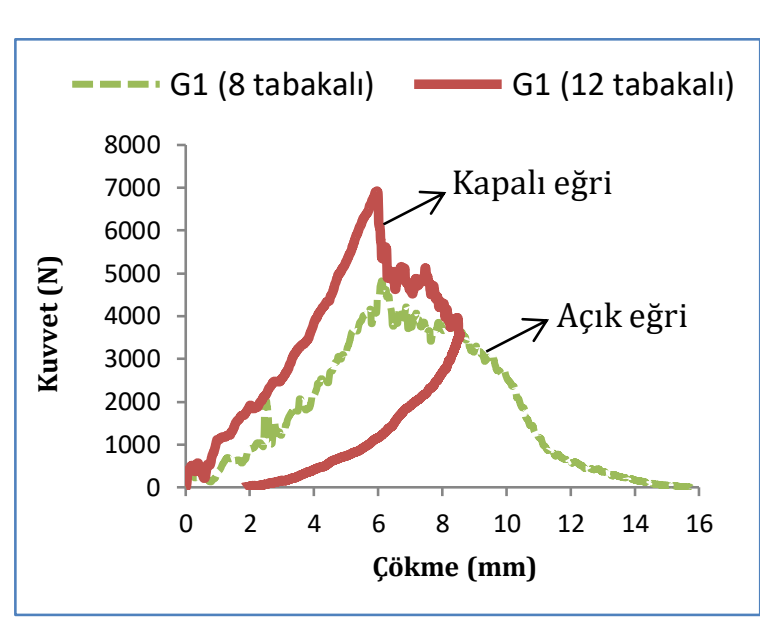

(c) 30 joule

Şekil 7. 8 ve 12 tabakalı 1. grup numuneleri için kuvvet-çökme eğrileri 
Absorbe edilen enerji - zaman eğrilerinde vurucunun numune yüzeyinden geri sekmesi durumunda vurucunun sahip olduğu enerjinin tamamı numune tarafından absorbe edilemez. Bu durumda absorbe edilemeyen darbe enerjisi vurucunun numune yüzeyinden geri sekmesi için harcanır. Vurucunun numuneye saplanması durumunda vurucunun sahip olduğu darbe enerjisinin tamamı numune tarafindan absorbe edilir. Vurucunun numuneyi delip geçmesi durumunda ise vurucu ile numune arasındaki sürtünme eğrisinin altında kalan alanın da darbe cihazının programı tarafından hesaplanan absorbe edilen enerji miktarına katılmasından dolayı eğri yukarı doğru yönlenir (Sayer, 2009).
Şekil 8'de 8 tabakalı $G_{1}^{8}$ ve 12 tabakalı $G_{1}^{12}$ konfigürasyonlarına ait numunelerinin artan darbe enerjisi altındaki absorbe edilen enerji-zaman eğrileri verilmiștir. Bu șekilden, 8 tabakalı $\mathrm{G}_{1}^{8}$ numunesi için 30J darbe enerji değerinde eğrinin yukarı doğru yönlendiği dolayısıyla delinme meydana geldiği görülmektedir. Bu numune haricindeki diğer 8 ve 12 tabakalı kompozit numuneler için ise tüm darbe enerji seviyelerinde geri sekme meydana geldiğ görülmektedir. Dolayısıyla diğer numunelerin hepsi için vurucunun sahip olduğu enerjinin tamamı absorbe edilememiş ve absorbe edilemeyen darbe enerjisi, vurucunun deney numunelerinden geri sekmesi için harcanmıştır.

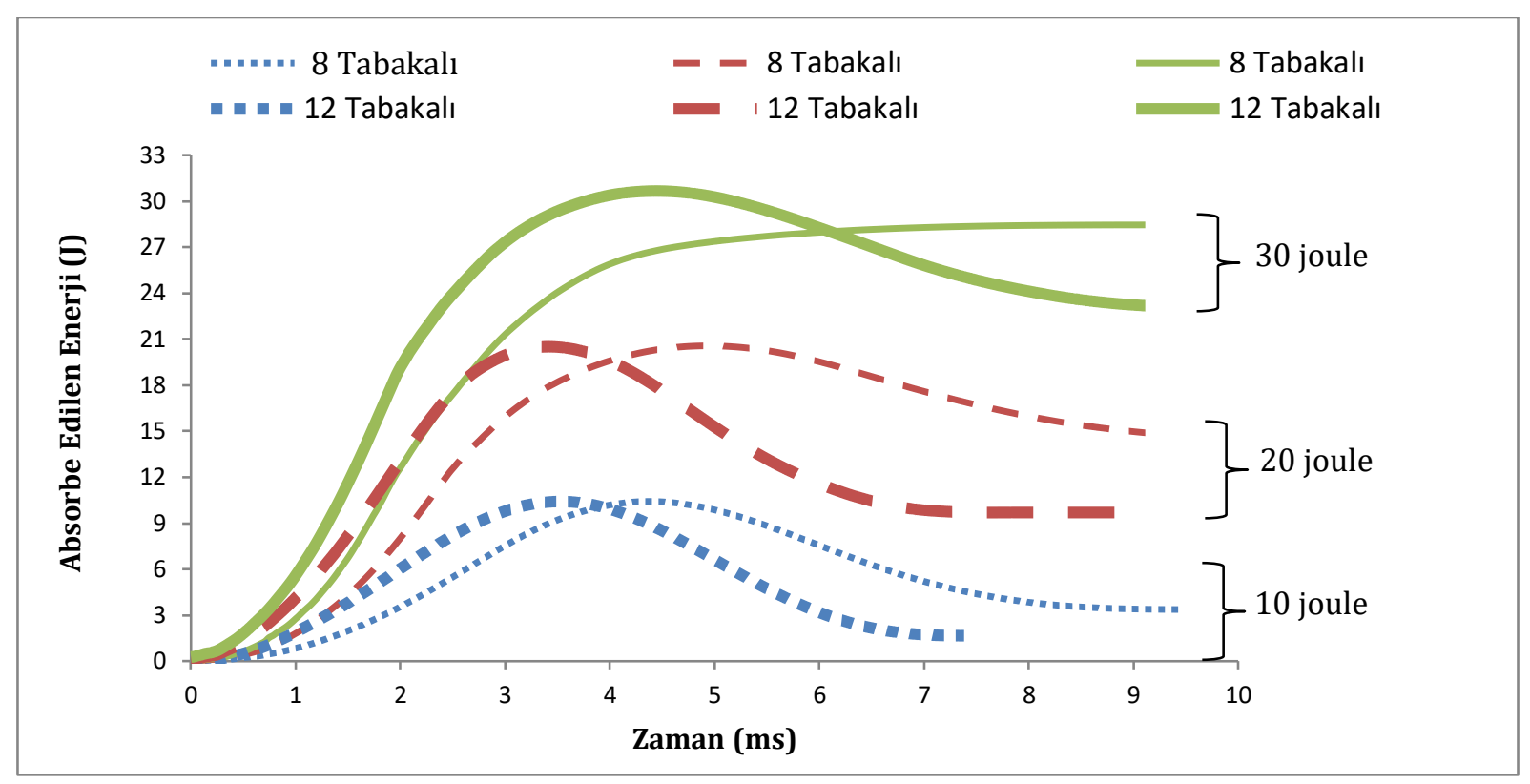

Şekil 8. 8 ve 12 tabakalı 1. grup numunelerin absorbe edilen enerji-zaman eğrileri

Şekil 9'da farklı oryantasyon açllarına sahip $G_{1}^{8}, G_{2}^{8}$ ve $G_{3}^{8}$ konfigürasyonlarına ait numunelerin çökmezaman eğrileri verilmiştir (Karacan, 2018). Şekilden görüleceği üzere $G_{1}^{8}, G_{2}^{8}$ ve $G_{3}^{8}$ numunelerinde $30 \mathrm{~J}$ darbe enerjisi altında delinme meydana gelirken, 10J ve 20J darbe enerjileri altında geri sekme meydana gelmiştir. Ayrıca 30J darbe enerji seviyesinde $\left[0^{\circ} / 90^{\circ} /\right.$ $\left.0^{\circ} / 90^{\circ}\right]_{\mathrm{s}}$ dizilimine sahip $\mathrm{G}_{1}^{8}$ numunesinde meydana gelen çökmenin, $\left[0^{\circ} / 30^{\circ} / 60^{\circ} / 0^{\circ}\right]_{\mathrm{S}}$ dizilimine sahip $\mathrm{G}_{3}^{8}$ numunesinden az, $\left[0^{\circ} / 90^{\circ} / 90^{\circ} / 0^{\circ}\right]_{\mathrm{s}}$ dizilimine sahip $\mathrm{G}_{2}^{8}$ numunesinden ise fazla olduğu görülmektedir. $\mathrm{Bu}$ durumda en büyük çökme miktarı $G_{3}^{8}$ numunesinde meydana gelmiştir.

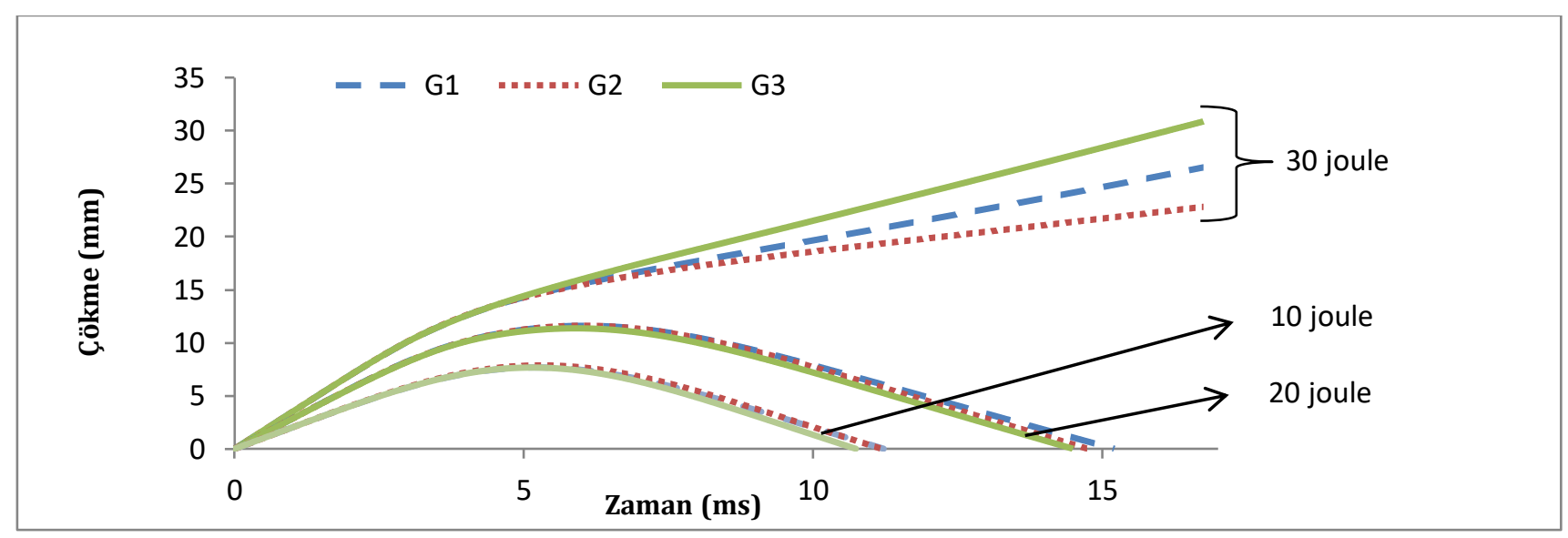

Şekil 9. Farklı oryantasyon açılarına sahip 8 tabakalı numunelerin çökme-zaman eğrileri 


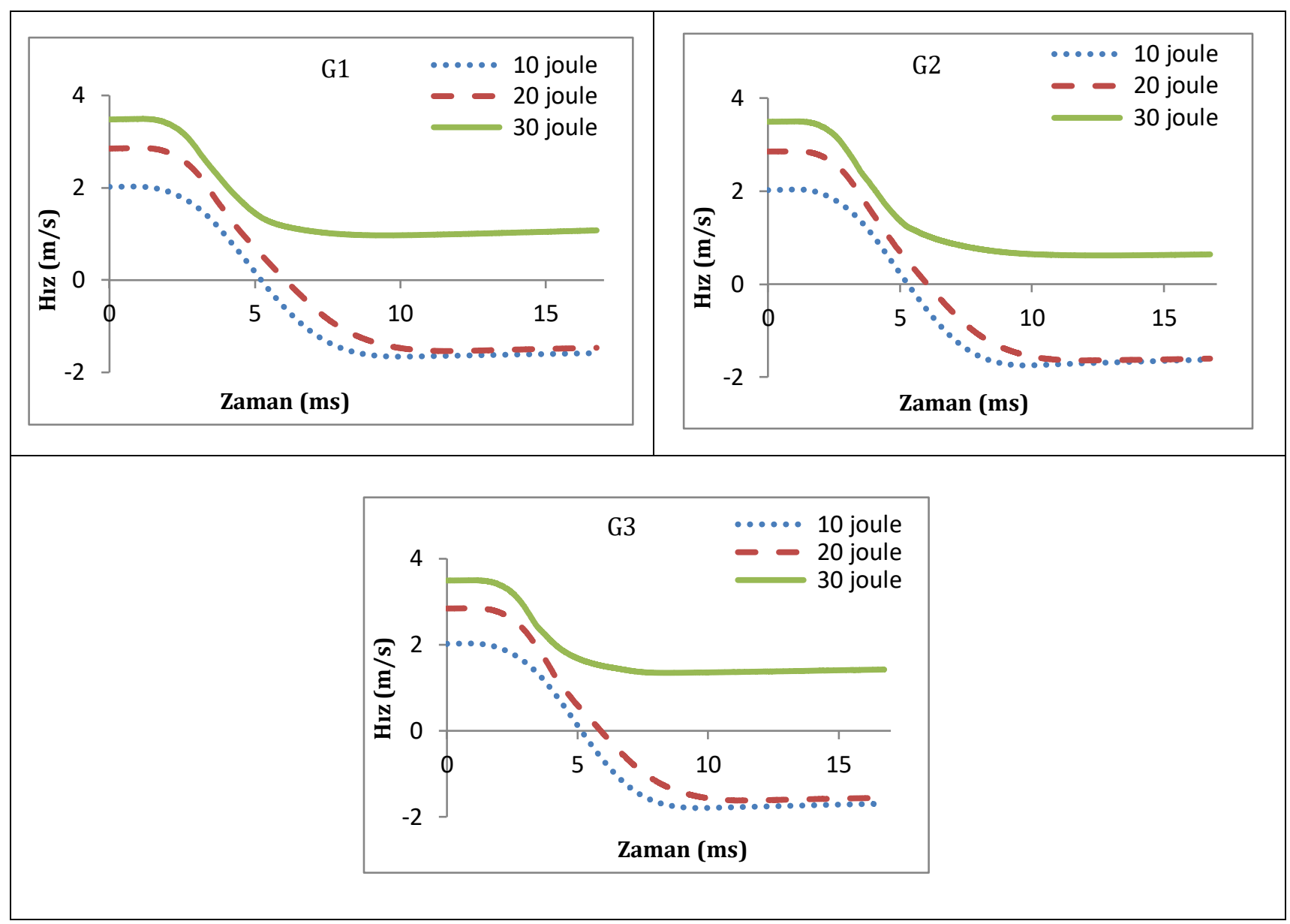

Şekil 10. Farklı oryantasyon sahip 8 tabakalı numunelerin hız - zaman eğrileri

Şekil $10^{\prime}$ da $G_{1}^{8}, G_{2}^{8}$ ve $G_{3}^{8}$ numuneleri için 30 J darbe enerji değerinde belli bir hız ile numuneye saplanıp kalınlık boyunca ilerleyen vurucunun hızı sürtünmeden dolayı yavașlamıștır. Bu yavașlamadan dolayı geri sekme meydana gelmemiş, numune delinme davranışı göstermiştir. 10J ve 20J darbe enerji değerlerinde ise ilk başta belli bir hıza sahip olan vurucunun numune ile ilk temasindan sonra hızı azalmıștır ve yukarı doğru hareket eden vurucunun negatif bir hız değeri alması ile geri sekme meydana gelmiştir.

Tabakalı kompozit malzemelerde üst yüzeye darbe uygulanması sonucu öncelikle matriste hasar oluşur. Matristeki hasar çatlak oluşumu ile başlar ve bu çatlak ilerleyerek matris kırılmalarına neden olur. Matrisin aşırı zorlanması sonucu gerilmeler liflere aktarılır ve lifler zorlanmaya başlar. Ayrıca matris kırılmaları delaminasyonun (tabakalar arası ayrılmaların) başlamasında da etken rol oynar. Üst katmanlardaki çatlak ve kırıklar arayüzeye ulaştığında diğer katman tarafindan durdurulur ve katmanlar arasında delaminasyon olarak ilerlemeye başlar. Delaminasyon aynı katman grubundaki tabakalar arasında değil, farklı fiber oryantasyonlarına sahip tabakalar arasında meydana gelen bir hasardır. Tabakalı kompozit malzemede katmanlar arasındaki farklı fiber yönlenmelerinden dolayı bu katmanların eğilme rijitlikleri de farklılıklar gösterir. Delaminasyonun en önemli sebebi tabaka arasındaki bu eğilme rijitlik farklılığı ve eğilme kaynaklı gerilmelerdir. Tabakalar arası eğilme rijitliğindeki uyuşmazlık ne kadar büyük olursa delaminasyon alanı o kadar büyük olur (Ceyhun ve Turan, 2003). Üst yüzeydeki katmanlarda darbe sonucu meydana gelen bası ve kesme gerilmeleri sonucu matriste oluşan kırılmalar kompozitin iç bölgesinde delaminasyonlara sebebiyet verir. Kompozitin iç bölgelerinde oluşan düşey eğilme kırıklarının büyümesi sonucu zorlanmayan en alt ara yüzeyde de delaminasyon başlar. Alt yüzeydeki katmanlarda meydana gelen eğilme gerilmeleri sonucu ise, eğilmeye bağlı olarak fiber-matris arayüzey bağı kopar, matriste ve fiberde kırılmalar oluşur. En alt yüzeyde, eğilmeden kaynaklanan çekme gerilmelerinin en fazla olması ve bu yüzeydeki liflerin en fazla çekme uzamasına maruz kalmasından dolayı fiber ve matris malzemesinde kırılmalar artar ve delinme hasarı meydana gelir.

Şekil 11'de 20J ve 30J darbe enerjisi uygulanan $G_{3}^{8}$ numunelerinin darbe sonrası alt yüzey hasar bölgelerinin fotoğrafları örnek olarak verilmiștir. Şekilden görüldüğü üzere, 20J uygulanan $\mathrm{G}_{3}^{8}$ numunesinin en alt katmanında eğilmeden kaynaklı 
çekme gerilmelerinin fazla olması nedeniyle dış yüzeyde tek yönlü fiber uzamaları ve fiberin matris malzemeden ayrılması durumu sözkonusudur. 20J darbe enerjisinde fiber uzamalarının en alt tabakadaki fiberlere paralel doğrultuda oluştuğu görülmektedir. 30J darbe enerji seviyesinde numunenin alt yüzeyinde oluşan hasar bölgesinin daha da genişlediği görülmektedir. Numuneye daha büyük darbe enerjisi uygulandığından alt yüzeydeki tabakalarda eğilme gerilmelerinin etkisi daha büyük olacaktır. Bunun sonucu olarak da numunenin alt yüzeyinin en diş tabakasındaki fiberlerde çift yönlü uzamaların yanısıra çift yönlü kalıcı fiber ayrılmalarının oluştuğu görülmektedir. Alt yüzeyde eğilmeden kaynaklanan çekme gerilmeleri en fazla olacağından hasar bölgesinin orta kısmında fiber ve matris malzeme eğilmeden kaynaklanan çekme gerilmelerini daha fazla taşıyamadığından numunede delinme meydana gelmiştir.

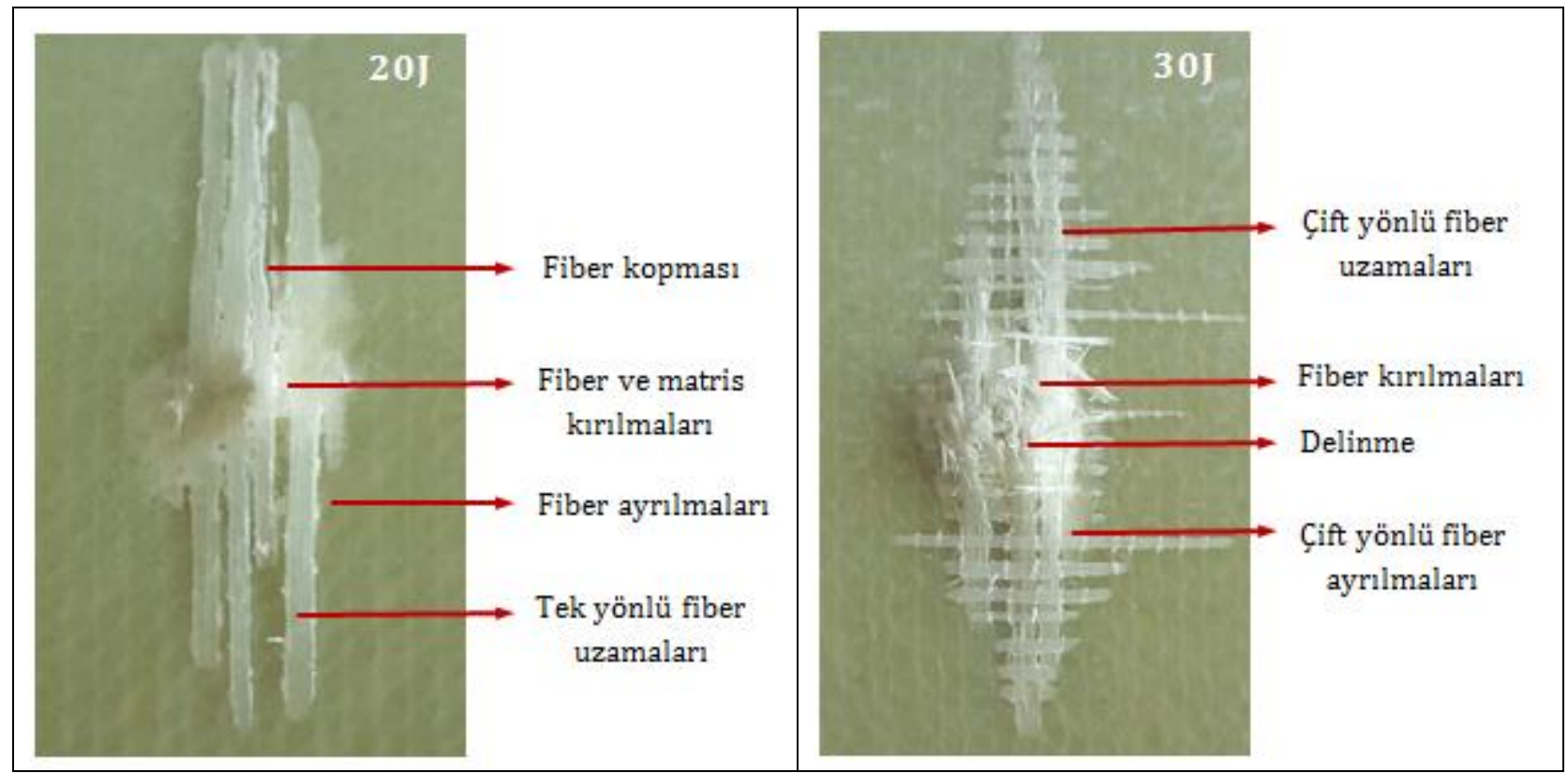

Şekil 11. 20j ve 30 joule darbe enerjisi uygulanan $G_{3}^{8}$ numunelerinin darbe sonrası alt yüzey hasar fotoğrafları

Şekil 12'de 8 tabakalı 2. grup $\mathrm{G}_{2}^{8}$ numunelerinin darbe sonrası alt yüzeylerinde oluşan hasar görüntüleri verilmiștir. Şekilden artan darbe enerjilerinde hasar bölgesinin genişlediği bariz bir şekilde görülmektedir. $\mathrm{G}_{2}^{8}$ numunelerinde 20J ve 30J için oluşan hasarlar Şekil 11 'de verilen $G_{3}^{8}$ numunelerinin darbe sonrası hasar bölgeleri ile karşılaştırıldığında, $\mathrm{G}_{2}^{8}$ numunelerinin darbe sonrası alt yüzey hasar bölgelerinin $\mathrm{G}_{3}^{8}$ numunelerinin alt yüzey hasar bölgelerine nazaran küçük olduğu görülmektedir. $\mathrm{G}_{2}^{8}$ numuneleri $\left[0^{\circ} / 90^{\circ} /\right.$ $90^{\circ} / 0^{\circ} / 0^{\circ} / 90^{\circ} / 90^{\circ} / 0^{\circ}$ ] dizilimine sahip olduğundan kompozitin ara bölgesi aynı yönlü fiberlere sahip iki katmandan oluşmakta ve bunun sonucu olarak ta darbe sonucu oluşan eğilmeye karşı kompozitin direnci daha fazla olmaktadır. $\left[0^{\circ} / 30^{\circ} / 60^{\circ} / 0^{\circ}\right]_{\mathrm{s}}$ dizilimine sahip $G_{3}^{8}$ numunelerinde ise katmanlar farklı yönlü fiberlerden oluştuğundan $G_{3}^{8}$ numunelerinin darbeye karşı cevabı, $G_{2}^{8}$ numunelerine nazaran daha düşük olmaktadır.

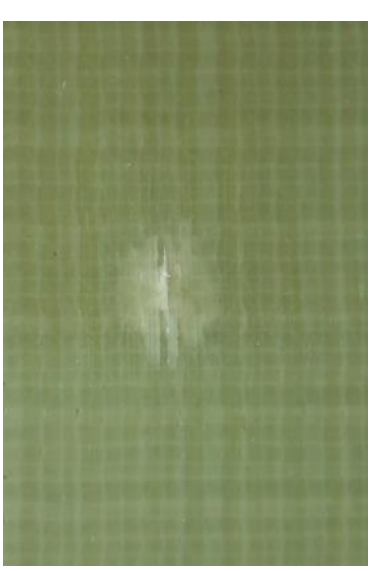

10 joule

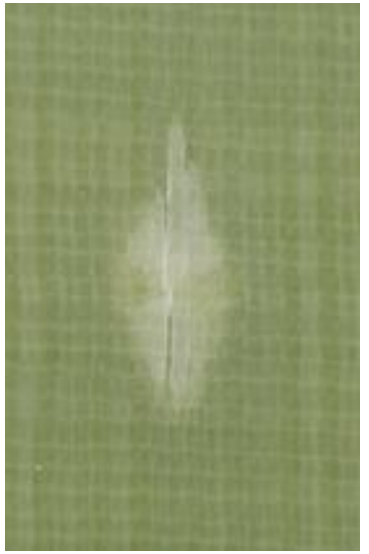

20 joule

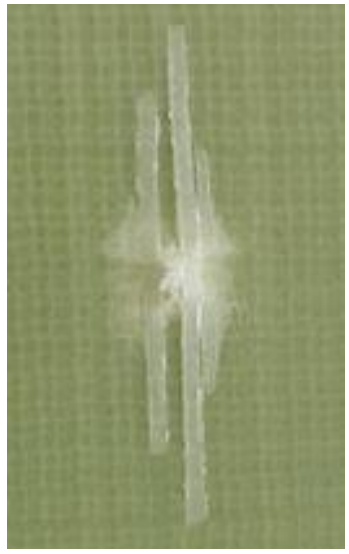

30 joule 
Şekil 12. 8 tabakalı 2. grup $\mathrm{G}_{2}^{8}$ numunelerin darbe sonrası alt yüzeylerinde oluşan hasar görüntüleri

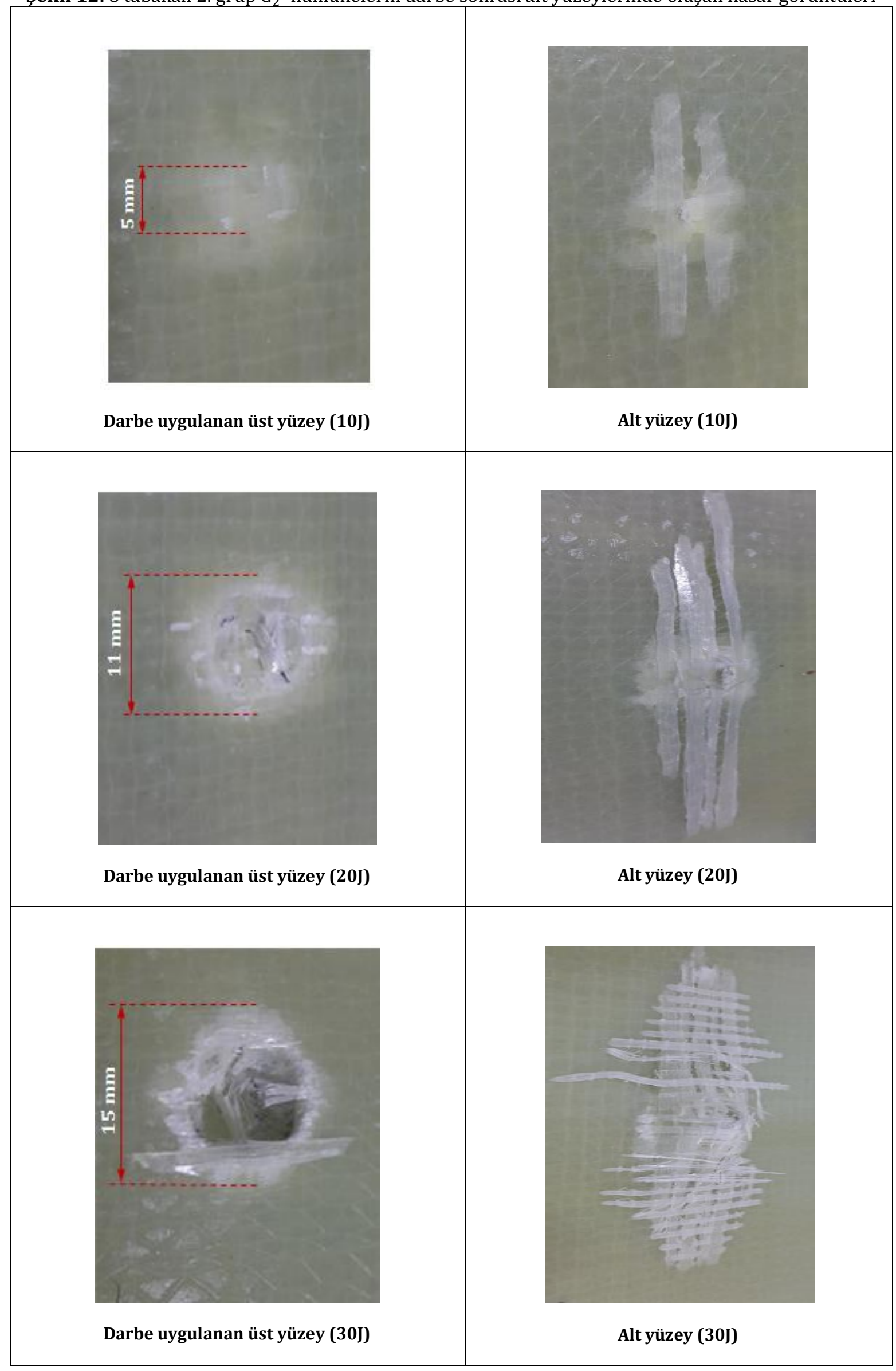


Şekil 13. Farklı joule değerleri için $G_{1}^{8}$ numunelerinin darbe sonrası üst ve alt yüzey hasar bölgesi fotoğrafları

Şekil 13'de üç farklı darbe enerjisi için 8 tabakalı 1. grup $\mathrm{G}_{1}^{8}$ numunelerinin üst ve alt yüzeylerinin hasar bölgesi fotoğrafları verilmiştir. Şekilden görüleceği üzere 10J enerji seviyesi için darbe uygulanan üst yüzeyde matris malzemesinde ezilme izi görülürken, 20J darbe değerinde ezilme alanının genişlediği, matris çatlaklarının oluștuğu ve çökmenin başladığı görülmektedir. 30J'lük darbe değerinde fiberlerin konkav șekil almaya zorlanması ile fiber boyları uzamaya çalışır. Buna bağlı olarak fiber kırılmaları ve delinme meydana gelmiștir. Bunun yanısıra darbe enerjisinin artmasiyla hasar bölgesinin matris malzemeyle birlikte fiberleri de içerecek şekilde daha da genişlediği gözlenmektedir. 10J enerji seviyesi için üst yüzeydeki hasar bölgesinin genişliği $5 \mathrm{~mm}$ iken, 20J seviyesinde $11 \mathrm{~mm}$ olarak ölçülmüştür. 30J seviyesinde bu genişliğin 15mm'ye çıktığı, çukurlaşmanın arttığı, çukurlaşmanın olduğu bölgedeki fiberlerde kopmaların meydana geldiği görülmektedir. $\quad G_{1}^{8} \quad$ numunelerinin darbe uygulanmayan alt yüzeyinde ise 10J darbe değeri için fiberlerin tek yönlü olarak uzadıkları ve matris malzemeden ayrılmaya başladıkları görülürken, 20J darbe değerinde fiberlerin daha fazla uzadığı ve kalıcı fiber ayrılmalarının meydana geldiği görülmektedir. $30 j^{\prime}$ lük darbe değerinde ise eğilme gerilmelerinden dolayı hem eksen doğrultusunda hem de eksene dik yönde çift yönlü fiber uzamalarının oluştuğu görülmektedir. Ayrıca çoklu fiber ayrılmaları meydana gelmiştir. Eğilmede en fazla çekme gerilmelerinin ve fiberlerin çekme uzama değerlerinin numunenin bu kısmında oluşmasının sonucu olarak da numunede fiber ve matris kırılmaları ile delinme hasarı oluşmuştur. 10J ve 20J darbe değerlerinde alt yüzeyde oluşan fiber uzamaları tek yönlü (en dış tabakadaki fiber doğrultusunda) iken, 30J darbe değerinde bu yüzeyde çift yönlü fiber uzamalarının oluştuğu görülmektedir. Sonuç olarak, her iki yüzeyde de darbe enerji değeri arttıkça hasar bölgesinin genişlediği görülmektedir. Tüm darbe enerji değerleri için darbe uygulanmayan alt yüzeydeki deformasyon alanının, darbe uygulanan üst yüzeydeki deformasyon alanına göre daha büyük olduğu görülmektedir.

\section{Sonuç ve Tartışma}

Yapılan deneysel çalışma sonucunda, artan darbe enerjisi altındaki cam elyaf/epoksi kompozit malzemelerinin darbe davranışı üzerine fiber takviye açılarının ve tabaka kalınlıklarının etkileri araştırılmış ve aşağıdaki sonuçlar elde edilmiştir:

- Artan darbe enerjisi değerlerinde maksimum kuvvet ve çökme miktarı değerleri de artmaktadır.

- Darbe uygulanmayan alt yüzeydeki deformasyon alanının darbe uygulanan üst yüzeydeki deformasyon alanına göre daha büyük olduğu görülmüştür.

- 8 tabakalı $\mathrm{G}_{1}^{8}, \mathrm{G}_{2}^{8}$ ve $\mathrm{G}_{3}^{8}$ numuneleri için $10 \mathrm{~J}$ ve $20 \mathrm{~J}$ enerji değerlerinde kapalı eğri oluşurken, 30J enerji değerinde açık eğri oluşmuştur. 12 tabakalı $\mathrm{G}_{1}^{12}$ numunelerinde ise tüm joule değerleri için kapalı eğri oluşmuştur.

- Artan darbe enerji değerlerinde, tabaka sayısının azalması durumunda kuvvet-çökme eğrileri kapalı eğriden açık eğriye geçme eğilimi göstermiştir.

- 8 tabakalı $\mathrm{G}_{1}^{8}$ numunelerinin yük taşıma kapasiteleri ve darbe dayanımları 12 tabakalı $\mathrm{G}_{1}^{12}$ numunelerine göre daha düşüktür.

- Farklı oryantasyon açlarına sahip olan 8 tabakalı $\left(G_{1}^{8}, G_{2}^{8}\right.$ ve $\left.G_{3}^{8}\right)$ numuneler artan darbe enerjisi altında benzer darbe davranışları göstermişlerdir. 8 tabakalı üç grupta oluşan çökme miktarları ve maksimum kuvvetler açısından sıralamanın $G_{2}^{8}<$ $\mathrm{G}_{1}^{8}<\mathrm{G}_{3}^{8}$ şeklinde olduğu görülmüştür.

- 30J darbe enerjisi için en fazla çökmenin $\left[0^{\circ} / 30^{\circ} /\right.$ $\left.60^{\circ} / 0^{\circ}\right]_{\mathrm{s}}$ dizilimine sahip $\mathrm{G}_{3}^{8}$ numunelerinde, en az çökmenin ise $\left[0^{\circ} / 90^{\circ} / 90^{\circ} / 0^{\circ}\right]_{\mathrm{s}}$ dizilimine sahip $\mathrm{G}_{2}^{8}$ numunelerinde oluştuğu görülmüştür.

- Cam elyaf/epoksi kompozit numunelerde düşük darbe enerjisinde, darbe uygulanan üst yüzeyde ezilme izi ve matris çatlakları gözlemlenmiştir. Darbe enerjisinin arttırılmasıla matris çatlaklarının ilerleyerek kırılmalara dönüştügü ve hasar bölgesinin genişlediği görülmüştür. Darbe uygulanmamış olan alt yüzeyde düşük darbe enerjisinde fiber uzamaları ve fiber ayrılmaları gözlenmiştir. Darbe enerjisinin arttırılmasıyla bu yüzeyde oluşan fiber uzamalarının ve hasar bölgesinin daha da genişlediği, dış katmanlardaki matris ve fiberlerin birlikte kırılması sonucu delinme hasarının gerçekleștiği görülmüștür.

- Kompozitin darbe uygulanmayan yüzeyinde eğilmeden kaynaklanan çekme gerilmelerinin en fazla olması ve bu yüzeydeki liflerin en fazla çekme uzamasına maruz kalmasından dolayı fiber ve matris malzemesinde kırılmalar artarak delinme hasar modu oluşmuştur.

\section{Teşekkür}

Bu çalışma, Süleyman Demirel Üniversitesi Bilimsel Araştırma Projeleri Koordinasyon Birimi tarafından 4941-YL1-17 nolu proje kapsamında desteklenmiştir. SDÜ Bilimsel Araştırma Projeleri Koordinasyon Birimi Başkanlığı'na katkılarından dolayı teşekkür ederiz. Ayrıca kompozit malzemelerin üretimini gerçekleştiren Fibermak Kompozit Firmasına ve 
deneyleri gerçekleştirdiğimiz Dokuz Eylül Üniversitesi Makine Mühendisliği Bölümüne de teşekkürlerimizi sunarız.

\section{Conflict of Interest / Çıkar Çatışması}

Yazarlar tarafından herhangi bir çıkar çatışması beyan edilmemiştir.

No conflict of interest was declared by the authors.

\section{Kaynaklar}

Abrate, S., 1998. Impact on Composite Structures. Cambridge University Press, 289s, United Kingdom.

Aktaş, M., Ataş, C., İçten, B.M. Karakuzu, R., 2009. An Experimental Investigation of the Impact Response of Composite Laminates. Composite Structures. 87, 307 313.

Aslan, Z., Karakuzu, R., Okutan, B., 2003. The Response of Laminated Composite Plates under Low-Velocity Impact Loading. Composite Structures. 59, 119-127.

Baucom, J.N., Zikry, M.A., 2005. Low Velocity Impact Damage Progression in Woven E-Glass Composite Systems. Composites, 36, 658-664.

Belingardi, G., Vadori, R., 2003. Influence of the Laminate Thickness in Low Velocity Impact Behavior of Composite Material Plate. Composite Structures, 61, 27-38.

Bulut, B., Karakuzu, R., İçten B. M., Arıkan, V., Arman, Y., Ataş, C., Gören, A., 2016. An Experimental and Numerical Investigation on Low Velocity Impact Behavior of Composite Plates. Journal of Composite Materials, 50 (25), 3551-3559.

Caprino, G., Spataro, G., Luongo, S.D., 2004. LowVelocity Impact Behaviour of Fiber Glass-Aluminium Laminates. Composites: Part A, 35, 605-616.

Ceyhun, V., Turan, M., 2003. Tabakalı Kompozit Malzemelerin Darbe Davranışı. Mühendis ve Makine, 44 (516), 35-41.

Datta S., Krishna, A. V., Rao, R. M. V. G. K., 2004. Low Velocity Impact Damage Tolerance Studies on GlassEpoxy Laminates-Effects of Material, Process and Test Parameters. Journal of Reinforced Plastics and Composites, 23 (3), 327-345.

Hosur, M.V., Adbullah, M., Jeelani, S., 2005. Studies on the Low-Velocity Impact Response of Woven Hybrid Composites. Composite Structures, 67, 253-262.

Kara, M., 2012. Düşük Hızlı Darbe Sonrası Yama ile Tamir Edilmiş Filaman Sarım CTP Boruların İç Basınç
Altındaki Hasar Davranışı. Selçuk Üniversitesi, Fen Bilimleri Enstitüsü, Doktora Tezi, 126s, Konya.

Karacan, A., 2018. Darbe Sonrası Farklı Ortam Koşullarına Maruz Bırakılan Kompozit Plakaların Basma Mukavemetlerinin Belirlenmesi. Süleyman Demirel Üniversitesi, Fen Bilimleri Enstitüsü, Yüksek Lisans Tezi, 85s, Isparta.

Kessler, A., Bledzki, A.K., 1999. Low Velocity Impact Behavior of Glass/Epoxy Cross-Ply Laminates with Different Fiber Treatments. Polymer Composites, 20 (2), 269-278.

Kıratlı, S., 2012. Darbe Hasarlı Tabakalı Kompozitlerin Burkulma ve Esneklik Davranışı. Cumhuriyet Üniversitesi, Fen Bilimleri Enstitüsü, Yüksek Lisans Tezi, 73s, Sivas.

Mili, F., Necib, B., 2001. Impact Behaviour of Cross-Ply Laminated Composite Plates under Low Velocities. Composite Structures, 51, 273-244.

Morais, de W. A., Monteiro, S.N., d'Almeida J. R. M., 2005. Effect of the Laminate Thickness on the Composite Strength to Repeated Low Energy Impacts. Composite Structures, 70, 223-228.

Naik, N. K., Borade, S. V., Arya, H., Sailendram, M., Prabhu, S. V., 2002. Experimental Studies on Impact Behaviour of Woven Fabric Composites: Effect of Impact Parameters. Journal of Reinforced Plastics and Composites, 21 (15), 1347-1362.

Naik, N. K., Meduri, S., Sekher, Y. C., 2000. Polymer Matrix Woven Fabric Composites Subjected to Low Velocity Impact: Part II-Effect of Plate Thickness. Journal of Reinforced Plastics and Composites, 19 (13), 1031-1055.

Sayer, M., 2009. Hibrit Kompozitlerin Darbe Davranışlarının İncelenmesi. Pamukkale Üniversitesi, Fen Bilimleri Enstitüsü, Doktora Tezi, 134s, Denizli.

Sierakowski, R.L., Nevil, G.E., Ross, A. Jones, E.R., 1971. Dynamic Compressive Strength and Failure of Steel Reinforced Epoxy Composites. Journal of Composite Materials, 5, 362-377.

Sierakowski, R.L. and Chaturvedi, S.K., 1997. Dynamic Loading and Characterization of Fiber-Reinforced Composites. New York, Wiley.

Uyaner, M., Kara, M., Ataberk, N., 2007. E Camı/Epoksi Tabakalı Kompozitlerin Düşük Hızlı Darbe Davranışına Numune Boyutlarının Etkisi. 8. Uluslararası Kırılma Konferansı Bildiriler Kitabı. 7-9 Kasım, İstanbul, 361-368.

Ylldızhan, İ., 2013. Hibrit Kompozit Malzemelerin Darbe Davranıșı. Süleyman Demirel Üniversitesi, Fen 
Bilimleri Enstitüsü, Makine Mühendisliği Anabilim Dalı, Yüksek Lisans Tezi, 83s, Isparta. 